Citation: Dołowy-Rybińska, N., \& Ratajczak, C. (2019). Languages and cultures in contact: The place of new speakers in the education system in Upper Lusatia. Cognitive Studies / Études cognitives, 2019(19). https://doi.org/ $10.11649 / \mathrm{cs} .1901$

\author{
NICOLE DOŁOWY-RYBIŃSKA ${ }^{1, A}$, CORDULA RATAJCZAK ${ }^{2, B}$ \\ ${ }^{1}$ Institute of Slavic Studies, Polish Academy of Sciences, Warsaw, Poland \\ 2"Serbske Nowiny", Bautzen, Germany \\ ${ }^{A_{\text {nicoledolowy@gmail.com }}}$ \\ https://orcid.org/0000-0001-7256-8226 \\ ${ }^{B}$ ratajczak@serbske-nowiny.de
}

\title{
LANGUAGES AND CULTURES IN CONTACT. THE PLACE OF NEW SPEAKERS IN THE EDUCATION SYSTEM IN UPPER LUSATIA
}

\begin{abstract}
Upper Sorbs are a Slavic minority group living in eastern Germany. The number of Upper Sorbian speakers is diminishing. Upper Sorbs, the majority of whom are Catholics, have a strong ethnic identity based on language, faith, and tradition and they form a rather closed community in relation to the surrounding German population. To counteract the process of language loss, the Sorbs have established an educational project called 'Witaj'. The continuation of this project is the '2 plus' program of bilingual education in schools, which has been implemented by the federal state of Saxony. The idea behind these initiatives is to connect native Upper Sorbian speakers and learners in order to facilitate the achievement of language competence and to break down existing ethnic boundaries. The realisation of this concept has encountered numerous problems. The German-speaking pupils involved often feel unmotivated to learn Sorbian and are often rejected by the Sorbian-speaking community as (potential) members.

This article presents the results of a research project examining the way young people from German-speaking homes who attend one of the Upper Sorbian middle schools acquire Sorbian language competence and how they create an identity in relation/opposition to their Sorbianspeaking peers. The analysis is based on the sociolinguistic observations of language practices conducted in the school in 2017 and on interviews with both native speakers and learners of Upper Sorbian. The article focuses on the following issues: relations between language practices, the necessary conditions for the active use of minority languages by learners, language and interpersonal contact, the acceptance of new speakers, and the creation of 'communities of practice'. Keywords: minority language learners; Upper Sorbian; bilingual education; new speakers; community of practice
\end{abstract}


Languages and cultures in contact. The place of new speakers in the education system in Upper Lusatia

\section{Introduction}

'New speakers' are not at all a new phenomenon. Those who could have been called 'new speakers' have existed whenever there has been contact between languages (Lim \& Ansaldo, 2016; Matras, 2009). Learning the language of one's neighbours or co-workers, or of a community, is a basic human need as it allows people to communicate, integrate and establish relationships. When we refer to new speakers of a language in the context of immigration, this concept does not pose any questions or doubts: a person living in the surroundings of a new language must learn it as quickly as possible so as to be able to function and to adapt to their new environment and society.

The situation is different in regard to new speakers of minority languages. In the European context, minority and regional languages exist in a situation of unequal bilingualism. The members of the minority group are expected to be bilingual, speaking the minority language while also being proficient in the dominant language. In contrast, the members of the dominant language group speak only the dominant language and are not encouraged to learn the minority language. When researching minority language communities in Europe, two opposite tendencies in speakers and potential speakers of these languages can be identified (Grenoble \& Whaley, 2006, p. 172). On the one hand, there is a strong feeling of inferiority, which results in different language ideologies (Schieffelin, Woolard, \& Kroskrity, 1998) and state policy. On the other hand, discourse about the benefits of multilingualism (Duchêne \& Heller, 2012) has become influential, as has the argument of the basic human need to find personal roots in a globalised world. Both these tendencies are based on the situation of minority speech communities in the 20th and 21st centuries.

To understand the importance of new speakers for the future of minority languages in Europe and elsewhere, we need to understand how language shifts have occurred. Simplifying a range of processes which are very complex and different for diverse groups, it could be said that during the 20th century the situation of language minorities in Europe changed significantly. Many factors contributed to this, such as industrialisation imposing a change in lifestyle; the extension of the railway system facilitating early emigration on a grander scale; urbanisation and the emergent break down of territorial communities; two world wars and their demographic and political effects and the mass media broadcasting initially only in the dominant languages. The dominant languages entered into spheres which until then had been reserved for the minority languages, and they became the synonymous with progress and modernity. This resulted in changes in people's lifestyles and led to acculturation. Add to this the openly hostile national policies of numerous states towards minority languages, and the interruption of the intergenerational transmission of these languages is understandable.

At the same time, at the turn of the 60's and 70's in Western Europe and after the political changes in Eastern Europe, social movements developed and led to the creation of new movements called 'ethnic revivals' (Smith, 1981). This precipitated the revaluation of minority languages and cultures by motivating people to resist, supplying them with adequate tools of pressure and political support. Facing the weakening of the intergenerational transmission of minority languages, the greatest effort was focused on the teaching of minority languages in schools. At the European level, language rights began to be treated also as human rights. The world's diversity of languages was recognised as something of value which should not be lost. Within this discourse, multilingualism also started to be presented positively, with numerous campaigns making people aware of the benefits of knowing as many languages as possible.

As mentioned above, the term 'new speakers' has gained importance recently in the milieu of researchers concerned with language minorities, with the last decade seeing numerous studies dedicated to this phenomenon (see O'Rourke, Ramallo, \& Pujolar, 2015; Smith-Christmas, Ó Murchadha, Hornsby, \& Moriarty, 2018). Thanks to the education system in/of some minority languages a new group of minority language learners has appeared. Sometimes they are called 'new speakers' although - as different studies show - in many cases the languages learned at school are not used on a daily basis. Proficiency and language competence depends on many factors: the language learning method, motivation, and practice - the use of a learned language. Therefore, 
there is a need to differentiate between minority language learners and new speakers.

Language learners are those who are learning a minority language at school or during particular courses. They may be motivated to become familiar with this language and to use it both in the classroom and outside school, but they may also participate in classes unwillingly and have no intention of speaking the language. Therefore, being a language learner does not imply acquiring language competence, or actively taking part in minority language practices.

With the notion of new speakers, the situation is much more complicated because in the milieu of those who deal with minority languages this phenomenon now has different research approaches to define it. Furthermore, the notion of a 'new speaker' depends greatly on the language community context.

The definition used in the research presented in this article is wide ranging as it combines some elements of other definitions. 'New speakers' are, therefore, individuals who have not learnt a language through conventional family transmission, or through exposure to its use within their local community (O'Rourke \& Pujolar, 2013). They make a constant effort to speak this language, regardless of their level of language competence (Hornsby, 2015). They begin to participate in, and/or identify themselves with, the speech community (Dołowy-Rybińska, 2017), and they struggle to be accepted and recognised as fellow speakers by the speech community (Ó Murchadha, Hornsby, Smith-Christmas, \& Moriarty, 2018). There are four important elements in this definition: 1) the process of learning a language (education); 2) the effort to use it (language practices); 3) the willingness to become a part of the 'speech community' (identity); and 4) being 'legitimized' as a speaker (recognition).

Most European language minorities have their own system of minority language education (although these systems vary greatly) and it is through education that most 'new speakers' are formed. Additionally, as different studies have shown, education at school does not necessarily translate into language practices, especially outside the classroom and when education ends. However, as will be seen in the example of the Upper Sorbian community, the most difficult process is that of becoming accepted and recognised as legitimate minority language speakers by the speech community. This depends not only on the motivation of the learners, but also on the "speech community' itself: their acceptance of 'new speakers' and their openness towards them.

It should be borne in mind that 'learners' and 'new speakers' of minority languages are influenced by the situation and status of the relevant minority language community. These factors may have a positive influence on the motivation of learners whose ancestors assimilated linguistically with the dominant language in the past, and who are now looking for opportunities to learn this minority language themselves or to persuade their children to learn it. They may also influence positively on the attitudes of some dominant culture members towards learning a minority language which for centuries was in an inferior position and which was not of any value on the linguistic market (Bourdieu, 1991) but which has now gained status as a language contributing to personal bilingual development. On the other hand, years and centuries of humiliation, inferiority, and ridicule have forced minority groups to develop survival strategies. They may have constructed imaginary boundaries to separate themselves from the dominant group and to protect their language and culture. In this case, various minority group language ideologies against learners and new speakers of their language may occur (see Costa, 2015). In this situation, the presence of learners and new speakers who come to a group with a willingness to speak their language and with ideas of how to protect the language may be difficult to accept. Consequently, there is a need to look at the situation of learners and new speakers of a minority language from both perspectives: the perspective of the minority group and that of those who are striving to learn the language. This article will concentrate on the latter, while bearing in mind the more or less conscious reasons for the strategies that have been chosen and applied by the Upper Sorbian community. 


\section{The Upper Sorbian community}

Sorbs live in eastern Germany, close to the Polish and Czech borders. They are the descendants of the Slavic tribes who settled from the 7th century in the area between the Elbe and the Saale. After the Middle Ages only the Sorbs in Lower and Upper Lusatia escaped Germanisation because of their unique situation in these territories. Statistics from the years 1884-1886 counted about 166,000 Sorbian-speaking people (Schön \& Scholze, 2014). As a result of industrialisation, lignite mining, the assimilationist policies of both the German Empire and the Weimar Republic, and the Nazis' anti-Sorbian policy, whose aim was the ethnic extermination of these Slavic people, the number of Sorbs was reduced by half by the years 1955/56 (Bott-Bodenhausen, 1997; Förster, 1995; Pech \& Scholze, 2003; Schön \& Scholze, 2014, p. 35). Although the results of post-war socialist policies towards the Sorbs are ambiguous (Meškank, 2011, 2016; Pech, 1999), in the GDR, for the first time in history, a Sorbian school system and state-funded Sorbian institutions were established.

The Sorbian community is divided into two distinct groups: Upper Sorbs, with up to 40,000 people who identify with this community and probably around 14,000 speakers of the Upper Sorbian language, and Lower Sorbs, with about 20,000 members and perhaps fewer than 3,000 speakers of the language (Elle, 2014, pp. 100 and next). These are approximate numbers: the last general sociolinguistic survey was conducted in the 1980s (Elle, 1992), with some partial research conducted in different parts of Lusatia afterwards (Jodlbauer, Spiess, \& Steenwijk, 2001; Norberg, 1996; Walde, 2004). However, the Sorbs themselves avoid such statistics, fearing that Germany could cut funding if the number of Sorbian languages speakers diminished drastically (Elle, 2010, 2011). ${ }^{1}$

The research presented in this article concerns the Upper Sorbian community only. Among Upper Sorbs there is a Catholic group who live close to Bautzen/Budyšin (Schön \& Scholze, 2014). They became a religious minority within the Slavic ethnic minority when - after the Reformation - 90 per cent of Sorbs chose Protestantism. Only the parishes belonging to monasteries of St. Marienstern and St. Peter in Bautzen/Budyšin remained Catholic. Nevertheless, in the 20th century Catholic Sorbs became the dominant Sorbian group. In the region between Bautzen/Budyšin, Wittichenau/Kulow and Kamenz/Kamjenc, with about 70 villages and approximately 6,500 Sorbian speakers (Elle, 2014, p. 101), the Sorbs are not only in the majority, but have also managed to maintain the intergenerational transmission of the Upper Sorbian language (Jaenecke, 2003; Walde, 2004). Catholic Sorbs kept Sorbian alive as an everyday language. Furthermore, in this region, and nowhere else, the schools offer classes in the Sorbian language (Pech, 1999, p. 113). Today, Sorbian Catholics also determine the public image of all Sorbs: Sorbians and Catholicism are seen as belonging together in media coverage (Tschernokoshewa, 2000, p. 88) and the Sorbian Catholic villages are looked upon as the core Sorbian region.

For the purposes of the research presented here it was important that Catholic Upper Sorbs form a group that separates itself from Germans with a threefold boundary: linguistic (Sorbian vs. German), ethnic (Sorbs/Slavs vs. Germans), and religious (Catholics vs. Protestants) (Schön \& Scholze, 2014). The community is built on a success story. With the high fertility of the loess soil of the St. Marienstern Monastery, and the resulting economic conditions, from early in the history of the region farmers developed an ethnic self-consciousness and demonstrated their national-religious self-awareness through different customs, such as Easter horse processions. They later achieved economic success and benefited from the educational opportunities of the GDR's socialist system (Keller, 2000, p. 60), and continued after the reunification of Germany. Today, the unemployment level is 4.5 per cent in the Sorbian Catholic community, much lower than in Saxony as a whole,

\footnotetext{
${ }^{1}$ Recently a former member of the right-wing populist party AfD gave new cause for these concerns in the parliamentary debate concerning the report of the Saxon State Government on the situation of the Sorbian people with the demand to count Sorbs. The unanimous public rejection - not only from Sorbian members of the parliament, but also from the Saxon Minister of Science and Culture - compared the counting of Sorbs with Nazi racism and their plans of Sorbian genocide (Sächsischer Landtag, 2018; "Wot wustawy so jara zdaluja", 2018).
} 
where it stands at 10 per cent (Budarjowa, 2018, p. 168). The birth-rate among Upper Sorbs is also higher than in the rest of the federal State of Saxony (Budarjowa, 2018, p. 165). The religious boundary limited the possibility of mixed marriages (Catholic-Protestant and therefore SorbianGerman) for many years up to 1945 (Walde, 2004). Although it was less strict in the GDR (Keller, 2000, p. 118), there is still a strong tradition of marriages between Catholic partners, preferably Sorbian.

In the Catholic region the Sorbian language has maintained the historic role of a 'sacred' language (Pollack, 2016, p. 6), and priests today still continue in their role of national-religious leaders and teachers. As Jaenecke (2003, pp. 227, 289) and Kimura (2015) have shown, they enable and support Sorbs, especially young people and families, to speak Sorbian. As a result of all these factors, Sorbian Catholics view the relation between identity, the cultivation of customs, and language use as inseparable and consider themselves to be the 'true/real Sorbs'. Nearly twenty years ago Tschernokoshewa analysed this phenomenon, taking into consideration the discourse of Catholic priests' as to who is a real Sorbian in terms of relations of power and the right to define it (Tschernokoshewa, 2000, p. 91).

Catholic Sorbs protect their community by avoiding integration with Germans: in the past and until the present this contact has always ended with the shift of the Sorbian language to German. It is also important to underline the fact that the attitudes of the surrounding Germans towards Sorbs and their language are far from positive: the German inhabitants of Lusatia in general accept Sorbs and their language, but on condition it is not used in their presence (Ratajczak, 2011 , p. 36). In other words, Sorbs can use their language in their private lives but they should be obliged to use German when in public. This discourse is so strong that it determines people's language practices: Sorbs avoid using their language in the presence of Germans. The 'bicultural normality' - accepted and practiced by both Germans and Sorbs - in Upper Lusatia is clearly divided. There are two parallel yet strictly separated worlds existing: one German and one Sorbian. The underlying logic of this dynamic is based on the assumption that no language contact means no cultural conflict. This strategy protects, on the one hand, the Germans from confrontation with a Slavic language they do not understand and, on the other hand, guarantees the right of the Sorbs to have their own sphere of language and cultural practices. When Sorbs move into the German world, they change their names, making their Sorbianness imperceptible and inaudible (Ratajczak, 1998, p. 144). When in the presence of Germans, they usually speak German with one another. To do otherwise would be to violate the rules of segregation, of avoiding contact with no mixed spheres. In other words, to enter the Sorbian world means being able to speak Sorbian.

This combination of Sorbian and German attitudes makes it especially difficult for Germanspeaking people to become 'new speakers' of the Sorbian language. Although the Upper Sorbian schools teaching in the ' 2 plus', bilingual system are. by definition Sorbian, the division into two worlds also exists in them.

\section{Upper Sorbian education}

Upper Sorbian language teaching was introduced in Lusatia as early as after World War II (Pjech, 2001). In 1952, in line with the official policy of bilingualism in Lusatia which was in place for a brief period, a division between 'A' forms (lessons conducted almost only in Upper Sorbian for pupils from Sorbian-speaking families) and 'B' forms (in which Upper Sorbian was taught as a second/foreign language to students of German-speaking families who wanted their children to know this minority language) was established. The idea was to make Sorbian-language education obligatory for all Sorbs. This situation continued until 1964, when a new regulation making the learning of Sorbian voluntary came into force. The number of pupils learning Sorbian diminished threefold in a single year. All efforts of the Domowina to change this policy failed. It is also important to underline that Germans did not take a positive view of the proposed solutions and that the educational results in ' $\mathrm{B}$ ' forms were not satisfactory. 
Following the transformation of the political system and the reunification of Germany, and with the significant decline in the number of children brought up in the Sorbian language, in the 1990s Sorbs initiated - at first only in pre-school classes - the 'Witaj' [Welcome] programme, an immersive type of education which was to be exclusively in Sorbian. Kindergartens that participated in the programme were attended by children of Sorbian-speaking and German-speaking families whose parents, for various reasons, wanted their children to learn Sorbian (Budarjowa, 2009; Kaulfürstowa, 2008). For the immersive education to produce results, the '2 plus' programme for primary and middle schools was initiated, in line with the educational concept recommended by the EU known as 'native language +2' (Gazsi, 2005; Rindler-Schjerve \& Vetter, 2012). In the case of Lusatia, the programme consists of instruction in two languages (German and Upper Sorbian) and the learning of a third language. Instruction in two languages was to allow young people from German-speaking homes to integrate linguistically with the Upper Sorbian speech community and become proficient in the language. The general idea of mixing language and cultural groups is also to provide the German-speaking children an entry into the Sorbian-speaking language community. The introduction of the ' 2 plus' concept into Upper Sorbian schools also aimed to raise awareness of the advantages resulting from bilingualism and multiculturalism in the area inhabited by Sorbs and Germans alike. However, the implementation of bilingual education diverted the idea from what the results should have been.

The Upper Sorbian schools in the Upper Sorbian-speaking area function today in the '2 plus' system. Pupils attend classes according to their Sorbian language competences: Upper Sorbian native speakers learn together and German-speakers are divided into further groups, ones with a basic level of Sorbian and ones with an intermediate level. This is also reflected in the construction of classes in middle school. After the beginning of middle school, all children are divided, based on their language competences, their parent's motivation and the individual opinion of a responsible teacher, into three types of classes.

There are thus three categories of classes in the ' 2 plus' system, in which only one represents a 'strong' form of education (leading to full bilingualism) while two represent a 'weak' form of minority language education, which does not really enable pupils to become proficient in the Upper Sorbian language (Skutnabb-Kangas \& McCarthy, 2008). This language group division lasts to the end of the 10th grade. From the 11th grade to the baccalaureate, the teaching system changes. During the two last years of student education, there is a system of courses chosen on the basis of individual interests and plans and this results in the mixing of the previous groups. However, because of the wide variation in the language competences of the pupils, most of the mixed courses are mainly conducted in German.

The problem discussed in this article, which has important consequences for non-native student opportunities, capacities and desires (Grin, 2003) to learn and to speak Upper Sorbian, is that the division between three groups which exists during most of school education is almost complete. This time at school is decisive for creating healthy relationships, but students share no lessons with peers from other language groups, and have almost no mixed afterschool activities, excursions, or events. They have no opportunities and, therefore, no need to get to know each other.

\section{Research methodology}

This article is based on research on the language practices and attitudes of the non-native students of an Upper Sorbian school. This research is of an interdisciplinary character. It was inspired by a sociolinguistic reflection on minority language practices and education (Baker \& Wright, 2017; García, 2016; Wright, Boun, \& García, 2015), and studies on new speakers of minority languages, combined with anthropological research based on participant observations of the pupils' language practices at school and in-depth interviews with students of the 11th grade. Other aspects of the study, not discussed within the frame of this article, are comprised of a statistical (quantitative) survey (see: Dołowy-Rybińska, 2018), and group discussions. 
The present article will concentrate on the problems of Upper Sorbian learners in the ' 2 plus' system and the challenges of becoming a 'new speaker' of the language based on the analysis of excerpts of in-depth interviews with 11th grade pupils. These pupils come mainly from the two types of classes for non-natives, although the picture is complemented with statements from native Sorbian speakers in order to show the relations and attitudes of both sides, as these also influence students' willingness to learn and use the language. There were 19 interviews recorded with pupils from 3 types of classes. Pupils could choose which language they wanted to speak during the interviews: Upper Sorbian or German. Excerpts from these interviews have been translated into English for this article, maintaining the oral, informal style of the statements.

This article presents part of the research which was conducted at the beginning of the 2017/2018 school year, when the study participants had just started 11th grade. This stage of education is particularly critical for the reasons described above: up to the 10th grade, the three types of Upper Sorbian language classes are separated and the lessons are in the same schooling system groups. Beginning with the 11th grade, students are no longer divided into classes. Instead, there is a system of courses and for the first time students from the three groups are mixed. Additionally, those teenagers at the age of 16 to 18 (as are the respondents) are mature enough to ask themselves questions of identity, and to be responsible for educational decisions. On the other hand, they are still strongly affected by outside influences and stereotypes current at school and within their communities concerning a minority group. Researchers are of the opinion that, for this reason, the high school can be treated as a 'hothouse for the construction of identities' (Eckert, 1998, p. 163). School creates special conditions that shape young people's attitudes and characters under conditions of certain alienation, which Kathryn Woolard (2011, p. 618), referring to the Michail Bakhtin's theory, named a 'distinct chronotope.' Therefore, it is reasonable to think that researching the attitudes and motivations of non-native students at the Upper Sorbian middle school can provide significant information about German-Sorbian relations, deepen understanding of the motivation and the conditions necessary to learn a minority language, and give some indications regarding minority language education in a situation of unequal bilingualism.

\section{Pupils' language practices}

Language practices in the school are very complex, as in any context with more than one language. As described earlier, there are pupils with different language competences in the school: Sorbian native-speakers who use the Upper Sorbian language among themselves but who usually switch to German when with other pupils; Upper Sorbian natives who speak mainly German among themselves and use Sorbian during lessons conducted in Sorbian; and Upper Sorbian language learners. Among this last group, we can distinguish those whose Sorbian language competences are high and who can easily understand Sorbian and often have some speaking language skills. They mainly attend bilingual classes. Nevertheless, not all pupils who are in bilingual education can be called 'new speakers' of Sorbian - some are hardly able to speak the language. Apart from them, there are those who may be called Sorbian language learners. In this group most of the pupils, after a few years of classes, cannot speak Sorbian and do not understand much. It may be that this results not only from the methods of language teaching and the educational system itself, but also from the lack of a school language policy which would favour Sorbian over German and encourage the use of Sorbian or Sorbian-German translanguaging (see García \& Wei, 2014) in school and during after-school activities.

The words of one girl, who represents a positive example of how it is possible to become an Upper Sorbian new speaker, illustrate the problems of the education system. She is from a Germanspeaking family but her parents decided to send her to the Sorbian native speaker's class despite the teacher advice that it would be too difficult for her. Today she speaks perfect Sorbian and feels quite integrated with the group. For the interview she chose to speak Sorbian. She describes the school language practices very clearly: 
NF20(S) $)^{2}:(.$.$) I would call it in German 'Schubkastendenken'. And it is often like this$ with these 'drawers' that when one is already there, don't change place. And when you say: these are the German or bilingual classes, then you speak with them in German, and with Sorbs you speak Sorbian. (...) When a Sorb thinks that you are 'Witaj' or that you don't speak Sorbian well, then he/she speaks to you in German and you have to repeat three times that, yes, you can speak Sorbian with me. But it is difficult to change the [language] habits.

Firstly, it is important to analyse the term 'Schubkastendenken', (a 'drawer way of thinking', an English-speaker might use the term 'pigeonholing'). It refers to the language categorisation made at the beginning of education which determines people's language practices during their whole time spent at school. In other words, Sorbs use the Sorbian language with other Sorbs but it is not treated seriously as a possible tool of communication between Sorbs and Germans. Although there are officially no longer any 'German' classes in the '2plus' system, the discourse of a double division of German and Sorbian worlds has also prevailed in the Sorbian school. It is not important whether a student is in the bilingual class, or if they have Sorbian family roots, kinship or other social relations. This categorisation ignores if a person has learnt Sorbian from childhood through the immersive 'Witaj' programme and speaks fluent Sorbian. Either a person is a Sorbian nativespeaker (and preferably from a Catholic community), or they are German (not only in linguistic, but also in ethnic/national terms). There is nothing 'in between', there is no common ground, and therefore there is no need to share the Sorbian language with 'Germans', even if they want to. Elka Tschernkoshewa ${ }^{3}$ has analysed the answers to the question, 'Am I a German or am I a Sorb?', as a dichotomous way of thinking, existing (not only) in Lusatia, which negates all the blended spheres of life, all the complicated biographies, families and relationships, the intertwined histories, experiences and language practices (Tschernokoshewa, 2013). The 'dream of purity' as a national paradigm of the 19th century still dominates in German-Sorbian relationships and provides no scope for hybridity. It prevents the opening of a 'third space', as Tschernokoshewa underlines, referring to theoreticians of post-colonial studies such as Homi K. Bhabha and Edward Saïd. It seems that the attempt of Tschernokoshewa to make hybridology a starting point of cultural research in Lusatia (Tschernokoshewa, 2013, p. 22), encountered the same obstacle as the 'Witaj' and '2plus' programmes in the Sorbian education system. This is how the statement of the Sorbian 'new speaker' that 'it is difficult to change habits' may be understood.

The girl quoted above was lucky to find herself in the Sorbian native speakers' class, a protected area of Sorbian language, from the start of secondary school. Here she experienced language immersion and was compelled to improve and to train her language competences constantly up to a native-speaker level. Learners who stay outside native speaker classes do not have this possibility. The boundary that defends the 'pure' Sorbian area, which was built up centuries ago and has been strengthened over the years, is too strong. It seems that there is only a theoretical chance of changing the existing, deeply internalised speech patterns. Without a strict school language policy, this will not happen.

\section{Pupil division and the consequences thereof}

The lack of contact between learners and native speakers can be identified as the main obstacle for learners starting to use the Sorbian language. The division between the group of Sorbian learners, which - as explained in the previous section - are treated by the school pupils and teachers as 'Germans', and the 'Sorbs', who come from Sorbian-speaking families and mainly from Catholic

\footnotetext{
${ }^{2}$ The naming system: $\mathrm{W}$ (learner)/ $\mathrm{N}$ (new speaker)/M (native-speaker); $\mathrm{F}$ (female)/M(male); 20 (symbol given to interviewee); $(\mathrm{S})$ interview in Sorbian / $(\mathrm{G})$ interview in German.

${ }^{3}$ Elka Tschernkoshewa was head of the cultural studies department of the Sorbian Institute in Bautzen/Budyšin for many years and editor of the series, 'Hybride Welten' (Hybrid Worlds) from the international publishing house, Waxmann.
} 
backgrounds, is almost total. This influences not only the students' sense of identity (both at school and outside school), but also the pupils' language practices. Here are the words of a girl who is a Sorbian language learner:

WF14(G): Well, not only linguistically [we feel separated]. Because it is still like this, (...) that these groups are sharply divided (...). I think now in the 11th grade for the first time we get together, through this course system German and Sorbian classes are no longer separated. In general, I think that the school made many mistakes when it came to separating German and Sorbian pupils. (...) yes [we feel like second-class students], but not just because of our schoolmates, also because of the teachers. Sometimes we just feel like we don't belong there. (...) And I don't think that this will really change in the next few years. Because it's just so deeply rooted.

This girl seems to be acutely aware of the consequences of the division amongst the pupils. This awareness is related to the recent changes in the system of learning. For the first time in this school, she has contact with native Sorbian pupils, and it makes her realize how much she has lost regarding the learning of the Sorbian language. She expresses how wide the division between Sorbs and Germans is. Once again, attention should be paid to how these terms are being used: 'Sorbs' are native-speakers of a language, members of a speech and cultural community. 'Germans' are those whose first language is German, regardless of their ethnic origin and expressed identity. This division has a significant influence on pupils' language and cultural choices.

For the first time, students who had been learning in different systems have the opportunity to get to know each other in the 11th grade, just two years before leaving school. Not only does this make it difficult for learners to practise their Sorbian, but they also often feel 'unwanted' at school. The respondent quoted above says that non-native Sorbian pupils feel like 'second class students' at school - as those who are not part of the Sorbian community. In addition, at least some of these students themselves feel that they do not belong, and that in the 'Sorbian' school their role is to justify statistics. Therefore, the German native speakers feel that the Sorbs do not treat them as part of the group. Furthermore, they often do not feel accepted as potential Sorbian language speakers. It certainly does not motivate them to study the language of people who ignore them or do not accept them as members of the community. The girl expressed the opinion that this division between 'Sorbs' and 'Germans' is too deeply rooted to be changed easily and quickly. However, the problem is even more acute: this division is maintained to subjugate the Sorbian community, because the Germans have always played the role of villains in Sorbian reality.

The strategy of dividing pupils leads to a lack of contact between Sorbian learners and native speakers at school. Not only are they separated at the beginning of their education, but this separation also increases during their years spent at school. The next extract is from an interview with a boy, also from the class of learners of Sorbian, who explains how this separation results in further ethnic and cultural division. He says:

WM12(G): (...) it appears that Sorbian pupils have better relations with other Sorbian pupils and (...) the other way round, the German students have better relations with each other than with the Sorbs. I think that the division is based here. So if we celebrate a birthday, for example, outside school, then most of the people invited are from our former class, they are all Germans. (...) When we engage socially, it's not like we're dealing with the Sorbs. (...) And this distinction is still strong, I would say.

This student states that the division and separation of the language groups at school is transferred to the level of social relations, making it impossible for pupils as a whole to build a community which would embrace both those who have German as a first language and native Sorbian speakers. This process is natural: when pupils start school they form strong relationships with those from the same class with whom they spend much of their time. They visit each other and share common interests and after-school activities. This translates into more durable relationships but they hardly speak with those from other classes during breaks between lessons. The boy admits that even when 
all classes are together, the social relations remain unchanged, which is reflected in his statement that they invite people from their former class to birthday parties. This is not due to any negative feelings against Sorbs, it is just because they know their German peers well and have very little or no contact with the Sorbian pupils.

Both the students quoted indicate the fact that a mixed community of pupils could have been created and strengthened if students had had more opportunities to get to know each other earlier and to organise something together. They admit that the feeling of community grows from the 11th grade. when all the pupils from the three types of classes are mixed, but this period only last two years. The consequences of this separation have more than merely social significance. The lack of contact between pupils makes it impossible for learners to practise the Sorbian language and to improve their language level, and hence to become 'new speakers'. Observations of pupils' language practices at school confirm that Sorbian-speaking pupils almost never speak Sorbian to those who were not in the 'native speakers' class, regardless of whether their interlocutor is able to speak some Sorbian or not. Vice-versa, the same applies: pupils from non-native classes who can speak Sorbian well, (almost) never use Sorbian in contact with native speakers, even if they speak it easily with their former class colleagues, and with other 'new speakers'.

The second level of this division is cultural, and also concerns the creation of communities. Not only does the division give non-native speakers fewer opportunities to practise Sorbian, as well as to get to know Sorbs and establish friendships with them, but it also has an adverse effect on their motivation to learn Sorbian and their willingness to become part of the Sorbian community. They simply do not participate in Sorbian social life. In the case of a minor language such as Upper Sorbian, the only possibility to use it is by entering a speech community: both at school and outside school. It is even more difficult for learners who have almost no contact with the Sorbian language outside school. The theory of situated learning (Lave \& Wenger, 1991) states that learning is the process of acquiring skills connected with living in a particular community and sharing common practices. Through this process, participants become conscious members of a specific community of practice (Eckert \& Wenger, 1994; Wenger, 1998). As can be observed, any sense of community among students which would embrace not only Sorbian native speakers but also Sorbian learners and new speakers starts to be built through mixed courses from the 11th grade only. However, even then this community is weak as it is not supported by shared activities apart from the main courses.

As a consequence, German pupils are separated from Sorbian culture and cultural life - they do not feel encouraged at school to participate in Sorbian cultural activities. As one girla also from the 'German' class, says:

WF15(G): We already have millions of full-time programs at this school, but actually I haven't participated in any. [The Sorbian events are] so far from here and if you know only those from the school there ... If I had friends living somewhere in those places, maybe [I would participate], but I do not have any.

What exactly does she tell us? First of all, she admits that the school offers many Sorbian activities, but that she has not participated in any of them. Indeed, the Sorbian secondary school is known for offering numerous after-school activities for pupils. Many of them have a Sorbian character. There is a Sorbian choir, performing Sorbian songs, which is well known in Lusatia and which is seen as a place where the Sorbian elite is forged. There is a Sorbian theatre group, a Sorbian dance group and an orchestra. Most of the non-native students who participated in the research have never even considered participating in these groups, presuming that these activities are for 'Sorbs' only. In fact, the learners of Sorbian do not feel encouraged to participate in Sorbian cultural life in the countryside (where the Sorbian speech community is based). The girl quoted above cites distance as the main reason: 'The Sorbian events are so far from here', she says. However, she then sheds light on the origin of the problem. Here, it is not distance that is the biggest problem, it is the lack of Sorbian friends who would integrate a 'German' into the group. She admits that if she had Sorbian friends, she would probably participate in Sorbian cultural life. However, she 
does not have any. This leads back to the fundamental problem of the separation of children at school.

Interestingly, from the perspective of native Sorbs this separation is downplayed. Here are the words of a Sorbian native-speaker girl:

MF1(S): In the choir, we have mainly native-speakers because we sing Sorbian songs and for Germans it would be difficult, and also because it is a bit of Sorbian tradition and customs. Because of that, it is slightly separated but when it comes to, for example, our Sorbian celebrations, we are not divided. A celebration is a celebration, and it is not that it is for Sorbs or Germans. Everybody can come and celebrate it together.

Trying to explain that non-native speakers could participate in Sorbian cultural life, she expresses all the Sorbian-speaker language ideologies which hinder German-speakers' entry to the Sorbian community. She explains the lack of non-natives in the choir by claiming that they are singing in Sorbian and that it would be too difficult for Germans. However, the language difficulty is not a major issue here, the choir also sings in languages other than Sorbian, and it is not too difficult for Sorbian speakers to sing these songs. The problem lies in the second part of the quote, where she says that 'it is a bit of Sorbian tradition and customs'. The relationship between Sorbian culture, language use and Catholic traditions will be analysed separately in the next section. Here, we can refer to the ideology of language (and culture) ownership related with the need to control the ownership of a language and to decide who can use it, when and with whom (O'Rourke, 2011). This ideology refers to the notion of a 'native speaker' who is a 'guardian' of a language. The ideology of language ownership goes beyond the language itself: it affects social relations and excludes learners from the speech community.

The girl claims that the Sorbian celebrations in the countryside are open to all and that German speakers can attend them. She does not ask herself why her non-native schoolmates do not participate in the events, to which they are supposed to feel invited. Listening to both sides provides an insight into the problem. In minority language education, not only are language competences important, but intercultural competences are significant, as are cross-cultural attitudes and behaviour, as they give learners a sense of belonging to a group. Learning a culture can 'be accomplished only through direct, sustained, and deep involvement with it' (Valdiviezo \& Nieto, 2015 , p. 94). In order to motivate learners to acquire and practise a minority language and to become new speakers, they should be immersed in a minority culture and speech community, because 'Language skills are no guarantee of continued use of that language into the teens and adulthood. Enculturation, therefore, becomes essential if that language is to be useful and used' (Baker \& Wright, 2017, p. 284). Sorbian language education does not offer much to enculturate Sorbian language learners.

According to Wenger, communities of practice must meet three conditions. Firstly, their members have to interact on different levels, with the result that a 'mutual engagement' is created. Secondly, all the participants should have common goals and activities, called 'joint enterprise'. Thirdly, they must 'share the repertoire' of resources connected with language, style and routines through which the group's identity is expressed (Wenger, 1998, pp. 72-85). It is through the existence of communities of practice in a minority language school that learners of a language may interiorize the language and feel that it is theirs, and in this way become new speakers. It is through these communities of practice that new speakers can integrate with native speakers, as the language becomes an additional aspect of their common activities. It is also through communities of practice that a new sense of a 'minority language community' is created (Dołowy-Rybińska, 2016). It would appear that this kind of community of practice, created by both native and non-native Sorbian speakers, does not exist in the school in which the research was conducted. Instead, this school maintains the existing division between ethnic Sorbs and ethnic Germans. In this division there is no place for new speakers of Sorbian. The roots of this division are strong, lying deep in the still existent Lusatian discourse of national purity which, as mentioned above, precludes any 
third space. Furthermore, the division is strengthened by the philosophy and culture of Sorbian Catholicism.

\section{Catholicism as an identity marker}

It is not possible to understand how difficult it is for Upper Sorbian learners to become new speakers without understanding how deeply Upper Sorbian culture is linked to the Catholic Church and the cultivation of Catholic folk customs. The background to these relations, as well as their influence and dominance today, has been presented in the introductory part of this article. This religious aspect also remains a determinant for language practices and identity in the younger generation. As most of the Sorbian learners come from non-Catholic families, it is difficult for them to be accepted and to be integrated into the Sorbian community. The explanation offered by this Sorbian native speaker speaks volumes in this respect:

MM5(S): Faith is strongly related in this (...). I don't think that in the future the Sorbian language will be maintained by (...) 'Witaj'. These institutions are important (...) but I see the Church as a pillar of Sorbianness (...). These are the villages that nurture Sorbian, and not the town. (...) There, the Sorbian language is practiced a great deal every week. (...) not only the language, but also these customs, and they have often a religious background. (...) If we only care about saving the language, and not what is related with this language, our culture, our customs... if we will lose them, then what is the language for? (...) The Sorbian language and the Catholic Church are so interrelated! And it is not possible to separate one from the other.

It is clear that Sorbs do not identify new speakers as fully legitimate actors in the revitalisation of their language, because the revitalisation process is related to the concept that Sorbian identity is inherent and that it expresses itself through the language. Both identity and language are related to tradition, which is (and must be in the future) Catholic.

What does the boy mean when he says that he sees 'the Church as a pillar of Sorbianness' and 'these are the villages that nurture Sorbian?' As Pauline Jaenecke shows in her study of the language preservation of the Catholic Sorbs, the way of life in Sorbian villages is characterized by 'merging religion and social life' (Jaenecke, 2003, p. 313). For centuries, the Catholic Church in Lusatia offered, through its unique position outside German institutions, a protected space for the Sorbian language, and basis for the linguistic, ethnic and religious boundaries between Sorbs and Germans. Unlike in everyday public life in the main town and capital of Upper Lusatia, Budyšin/Bautzen (Ratajczak, 2011), in Catholic Sorbian villages people are socially 'obliged' to speak Sorbian. And, as Jaenecke pointed out, it is the manner in which Catholicism shapes village communities that motivates the majority to speak Sorbian (Jaenecke, 2003, p. 343). This is also true for German-speakers who settle in these villages. If they were not Catholic and were unable to speak Sorbian they would have very little chance of integrating into the community. In contrast, for German-speaking Catholics who live in the Upper Sorbian Catholic area it is much easier to become a new speaker than for non-Catholics (see: Kimura, 2015).

To understand how completely the Catholic way of life dominates the community, as well as the lives of individuals, and closes it off from Germans and non-Catholics, it is necessary to examine the elements that comprise the structure of Sorbian space and time. As well as the sacraments (religious ceremonies) and related customs which accompany life from beginning to end, both boys and girls are obliged to serve as altar servers. Once a year they participate in a children's religious week. As teenagers, they join Catholic youth organisations and participate in activities and pilgrimages. Additionally, the majority of boys aged 14 and over take part in the Easter horse riding processions that connect the Catholic Sorbian villages. They attend church services (not only on Sundays), acquire the impressive culture of Sorbian religious singing, and participate in religious festivities. They establish relationships with each other (and with potential life partners) 
during the larger meetings, such as the Pentecost pilgrimage to Róžant/Rosenthal. The girls not only wear national costumes on religious occasions, but also during village festivities such as the Maypole dance. The entire year is structured this way, with events where the larger Sorbian speech community meets. Dancing events for the young or Sorbian music concerts are planned around the Catholic calendar. They do not take place during periods of fasting.

A young Sorb asks 'If we only care about saving the language, and not what is related with this language, our culture, our customs... if we will lose them, then what is the language for?' In the eyes of this interviewee it is the culture of this Catholic Sorbian world which has priority in the process of language maintenance. The Sorbian language is only a tool of communication, not the object which is to be preserved. From this perspective, it really does not make sense to learn Sorbian, as his German-speaking non-Catholic peers are trying to. Why should they, if there is no purpose, no 'real' life (meaning Catholic and Sorbian) behind it? If not through the Catholic community, learners would have to have other social practices shared with the native Sorbs in which a common language would foster a sense of community. For the boy quoted above, however, the only Sorbian world is in the Catholic villages, with Catholicism as the entrance ticket to it. None of the German-speaking respondents in the school has this ticket.

\section{Conclusion}

The main question this article aimed to answer is about the place of new speakers in the Upper Sorbian school system. This question remains important as the Sorbs have opened their schools to learners with the establishment of the 'Witaj' programme and the ' 2 plus' system. They have let German-speakers in, and have allowed them to believe that they will become bilingual. The reality observed during the research does not correspond to the aims of these initiatives. The German-speakers invest time and effort into learning Upper Sorbian but are rarely integrated into the Sorbian community. Consequently, the school is not an ideal place to become a new speaker of Upper Sorbian, although this situation has improved over the last several years. The concerns of native Sorbian-speakers are the result of the historic background and tensions between Sorbs and Germans. They can also be attributed to the strategy of isolation the Sorbs have developed in order to resist Germanisation. This is related to the language ideologies, which are still strong in Lusatia and which are not (yet) in the process of deconstruction, chiefly that the minority language should not be used in the presence of dominant language speakers. This ideology determines language practices and makes it particularly difficult for German-speaking learners of Upper Sorbian to become fluent in the language.

The second problem concerns the cultural separation of the Sorbian and German worlds. Both groups make little effort to enter into any meaningful interaction, to become acquainted with each other, or to establish relationships. Little curiosity is displayed for the minority culture, which would be necessary to motivate a person to learn the minority language. This is aggravated by the boundaries constructed over the centuries by the Catholic Sorbs, who feel that they are the 'owners' of the Upper Sorbian language and the only 'real' Sorbs. This threefold boundary requires newcomers to participate in a life they do not know and in customs which (for cultural and religious reasons) will never be theirs. For them to become new speakers of the Sorbian language, a new space, both cultural and linguistic, should be created. This is still a pressing challenge for Sorbian language education. The school should contribute to forming this space, where Upper Sorbian can been used as the language of different communities of practice and is not necessarily related to Sorbian traditions.

If one imagines the Upper Sorbian education system as a lens looking into the Upper Sorbian speech community, one can see some important indicators. Firstly, Sorbian and German pupils are continually divided. They are taught in the same school - just as Sorbs and Germans who live in the same territory - but they are separated. Even when pupils are finally in the same classes in the 11th grade, their relationships with friends from former groups (Sorbs for the native 
Sorbian-speakers and Germans for the non-natives) are already so strong that they tend to have little significant interaction with their new classmates. In addition, this division is reinforced by the fact that the Sorbian-speakers know each other from their villages and church life, while most of the German-speakers are from Bautzen/Budyšin. Most of the pupils enter the school as members of a certain community and they cannot change this situation at school because the school maintains this division.

This division makes it difficult for pupils to get to know each other and to create new forms of communities of practice which are not based on ethnic or linguistic terms but on shared activities offered by the school. The lack of such activities, and the school's deliberate language policy, increase the problems non-natives face integrating into the Sorbian speech community.

Sorbian and German culture and language are in constant contact as both groups inhabit the same territory. At the same time, it seems that this contact is often superficial. Germans have their preconceived notions about Sorbs and Sorbs hide their Sorbian identity when in contact with Germans. This state of affairs sheds new light on the question of 'new speakers' and their role in maintaining/revitalizing a minority language, particularly when a minority language is contested by the dominant group and appropriated by the minority. This problem demands further research.

\section{References}

Baker, C., \& Wright, W. E. (2017). Foundations of bilingual education and bilingualism (6th ed.). Bristol: Multilingual Matters.

Bott-Bodenhausen, K. (1997). Sprachverfolung in der NS-Zeit: Sorbische Zeitzeugen berichten. Bautzen: Domowina Verlag.

Bourdieu, P. (1991). Language and symbolic power. Cambridge: Polity Press.

Budarjowa, L. (2009). Witaj a 2plus - wužadanje za přichod [Witaj und 2plus - eine Herausforderung für die Zukunft]. Budyšin: Serbske šulske towarstwo.

Budarjowa, L. (Ed.). (2018). 20 lět/Jahre Witaj. Budyšin/Bautzen: Serbske šulske towarstwo z.t. / Sorbischer Schulverein e.V.

Costa, J. (2015). New speakers, new language: On being a legitimate speaker of a minority language in Provence. International Journal of the Sociology of Language, 2015(231), 127-145.

Dołowy-Rybińska, N. (2016). Language attitudes and community engagement: Diwan - The Breton immersion high school through the eyes of its pupils. Journal of Language, Identity, and Education, 15(5), 280-292. https://doi.org/10.1080/15348458.2016.1213134

Dołowy-Rybińska, N. (2017). "Nikt za nas tego nie zrobi": Praktyki językowe i kulturowe młodych aktywistów mniejszości językowych Europy. Toruń: Wydawnictwo Naukowe Uniwersytetu Mikołaja Kopernika.

Dołowy-Rybińska, N. (2018). Language practices of non-native Upper Sorbian learners in the Upper Sorbian Grammar School in Bautzen/Budyšin. Zeszyty Eużyckie, 52, 45-73.

Duchêne, A., \& Heller, M. (2012). Pride and profit: Changing discourses of language, capital and nationstate. In A. Duchêne \& M. Heller (Eds.), Language in late capitalism: Pride and profit (pp. 1-21). New York, NY: Routledge. https://doi.org/10.4324/9780203155868

Eckert, P. (1998). Age as a sociolinguistic variable. In F. Coulmas (Ed.), The handbook of sociolinguistics (pp. 151-167). Oxford: Wiley-Blackwell. https://doi.org/10.1002/9781405166256.ch9

Eckert, P., \& Wenger, E. (1994). Transition from school to work: An apprenticeship in institutional identity (Working Papers on Learning and Identity, 1). Palo Alto: Institute for Research on Learning. Retrieved from https://www.stanford.edu/ eckert/PDF/transition.pdf

Elle, L. (1992). Sorbische Kultur und ihre Rezipienten: Ergebnisse einer ethnosoziologischen Befragung. Bautzen: Domowina-Verlag Bautzen.

Elle, L. (2010). Sorben - demographische und statistische Aspekte. In M. T. Vogt, J. Neyer, D. Bingen, \& J. Sokol (Eds.), Minderheiten als Mehrwert (pp. 309-318). Frankfurt am Main: Peter Lang.

Elle, L. (2011). Wie viele Sorben gibt es - noch? Oder: Kann und soll man Minderheiten zählen? In E. Tschernokoshewa \& I. Keller (Eds.), Dialogische Begegnungen: Minderheiten - Mehrheiten aus hybridologischer Sicht (pp. 209-223). Münster: Waxmann. 
Elle, L. (2014). Sprachenpolitik in der Lausitz: Sprachenpolitik und Sprachenrecht im deutsch-sorbischen Gebiet 1990 bis 2014. Bautzen: Domowina Verlag.

Förster, F. (1995). Verschwundene Dörfer: Die Ortsabbrüche des Lausitzer Braunkohlenreviers bis 1993. Bautzen: Domowina-Verlag.

García, O. (2016). Bilingual education in the 21st century: A global perspective. Malden, MA: WileyBlackwell.

García, O., \& Wei, L. (2014). Translanguaging: Language, bilingualism and education. New York, NY: Palgrave Macmillan. https://doi.org/10.1057/9781137385765

Gazsi, O. (2005). 2plus: Schulartübergreifendes Konzept: Die zweisprachige sorbisch-deutsche Schule für allgemeinbildende Schulen im sorbischen Siedlungsgebiet. Radebeul: Comenius-Institut.

Grenoble, L. A., \& Whaley, L. J. (2006). Saving languages: An introduction to language revitalization. Cambridge: Cambridge University Press. https://doi.org/10.1017/CB09780511615931

Grin, F. (2003). Language policy evaluation and the European charter for regional or minority languages. New York, NY: Palgrave Macmillan. https://doi.org/10.1057/9780230502666

Hornsby, M. (2015). Revitalizing minority languages: New speakers of Breton, Yiddish and Lemko. New York, NY: Palgrave Macmillan. https://doi.org/10.1057/9781137498809

Jaenecke, P. (2003). Religiosität und Spracherhalt bei den katholischen Sorben. Berlin: Weißensee Verlag.

Jodlbauer, R., Spiess, G., \& Steenwwijk, H. (2001). Die aktuelle Situation der niedersorbischen Sprache: Ergebnisse einer soziolinguistischen Untersuchung der Jahre 1993-1995. Bautzen: Domowina-Verlag.

Kaulfürstowa, J. (Ed.). (2008). Das WITAJ-Projekt in Kindertagesstätten im Freistaat Sachsen - Zwischenbilanz und Ausblick in die Zukunft. Bautzen: WITAJ-Sprachzentrum.

Keller, I. (2000). Sorbische und deutsch-sorbische Familien. Drei Generationen im Vergleich. Bautzen: Domowina-Verlag.

Kimura, G. C. (2015). Spracherhalt als Prozess: Elemente des kirchlichen Sprachmanagements bei den katholischen Sorben. International Journal of the Sociology of Language, 2015(232), 13-32. https: //doi.org/10.1515/ijsl-2014-0040

Lave, J., \& Wenger, E. (1991). Situated learning: Legitimate peripheral participation. Cambridge: Cambridge University Press. https://doi.org/10.1017/CB09780511815355

Lim, L., \& Ansaldo, U. (2016). Languages in contact. Cambridge: Cambridge University Press. https: //doi.org/10.1017/CB09781139019743

Matras, Y. (2009). Language contact. Cambridge: Cambridge University Press. https://doi.org/10. 1017/CB09780511809873

Meškank, T. (2011). Kultura w stužbje totalitarneho režima: Wo wobstejnosćach w Serbach 1948-1989. Budyšin: Ludowe nakładnistwo Domowina.

Meškank, T. (2016). Sorben im Blick der Staatssicherheit: Die Akten des K5 und des MfS der DDR 1949-1989. Bautzen: Domowina-Verlag.

Norberg, M. (1996). Sprachwechselprozeß in der Niederlausitz: Soziolinguistische Fallstudie der deutschsorbischen Gemeinde Drachhausen/Hochoza. Uppsala: M. Nordberg. (Studia Slavica Upsalensia, 37).

Ó Murchadha, N. P., Hornsby, M., Smith-Christmas, C., \& Moriarty, M. (2018). New speakers, familiar concepts? In C. Smith-Christmas, N. P. Ó Murchadha, M. Hornsby, \& M. Moriarty (Eds.), New speakers of minority languages: Linguistic ideologies and practices (pp. 1-22). New York, NY: Palgrave Macmillan. https://doi.org/10.1057/978-1-137-57558-6_1

O'Rourke, B. (2011). Whose language is it? Struggles for language ownership in an Irish language classroom. Journal of Language, Identity, and Education, 10(5), 327-345. https://doi.org/10.1080/ 15348458.2011 .614545

O'Rourke, B., \& Pujolar, J. (2013). From native speakers to "new speakers" - problematizing nativeness in language revitalization contexts. Histoire Épistémologie Langage, 35(2), 47-67.

O'Rourke, B., Ramallo, F., \& Pujolar, J. (2015). New speakers of minority languages: The challenging opportunity. International Journal of the Sociology of Language, 2015(231), 1-20.

Pech, E. (1999). Die Sorbenpolitik der DDR 1949 - 1970: Anspruch und Wirklichkeit. Bautzen: DomowinaVerlag.

Pech, E., \& Scholze, D. (Eds.). (2003). Zwischen Zwang und Bestand: Deutsche Politik gegenüber den Sorben vom Wiener Kongress bis zur Gegenwart. Bautzen: Domowina-Verlag.

Pjech, E. (2001). The Sorbian school system in Germany 1945-2000. Education et Sociétés Plurilingues, $2001(10), 39-48$. 
Pollack, F. (2016). Wendische Prediger: Eine Kollektivbiografie der sorbischen evangelischen Geistlichkeit in der frühneuzeitlichen Oberlausitz (Doctoral Dissertation). Universität Leipzig, Leipzig.

Ratajczak, C. (1998). Zwischen "sorbischer Innen- und deutscher Außenperspektive": Grenz-Werte einer Mischkultur im Lausitzer Braunkohlentagebaugebiet. In R. Schneider (Ed.), "Grenzgänger" (pp. 135-146). Saarbrücken: Saarbrücker Druck u. Verl.

Ratajczak, C. (2011). Vom Image einer Minderheitensprache - Erfahrungen und Einstellungen Bautzener Schüler zum Sorbischen. Bautzen: Domowina-Verlag.

Rindler-Schjerve, R., \& Vetter, E. (2012). European multilingualism: Current perspectives and challenges. Clevedon: Multilingual Matters. https://doi.org/10.21832/9781847697363

Sächsischer Landtag. (2018, June 27). Plenarprotokoll 6/74: 74. Sitzung. Retrieved from https://www.1a ndtag.sachsen.de/de/aktuelles/sitzungskalender/protokoll/1165

Schieffelin, B., Woolard, K., \& Kroskrity, P. (1998). Language ideologies: Practice and theory. New York, NY: Oxford University Press.

Schön, F., \& Scholze, D. (Eds.). (2014). Sorbisches Kulturlexikon. Bautzen: Domowina-Verlag.

Skutnabb-Kangas, T., \& McCarty, T. L. (2008). Key concepts in bilingual education: Ideological, historical, epistemological and empirical foundations. In J. Cummins \& N. H. Hornberger (Eds.), Encyclopedia of language and education (2nd ed., pp. 3-17). New York, NY: Springer.

Smith, A. D. (1981). The ethnic revival. Cambridge: Cambridge University Press.

Smith-Christmas, C., Ó Murchadha, N. P., Hornsby, M., \& Moriarty, M. (2018). New speakers of minority languages: Linguistic ideologies and practices. New York, NY: Palgrave Macmillan. https://doi.or $\mathrm{g} / 10.1057 / 978-1-137-57558-6$

Tschernokoshewa, E. (2000). Das Reine und das Vermischte: Die deutschsprachige Presse über Andere und Anderssein an Beispiel der Sorben. Münster: Waxmann.

Tschernokoshewa, E. (2013). "Bin ich Deutscher oder Sorbe?": Wege und Irrwege zu einer hybridologischen Forschungsperspektive in der Lausitz. In E. Tschernokoshewa \& F. Jacobs, Über Dualismen hinaus: Regionen, Menschen, Institutionen in hybridologischer Perspektive (pp. 13-42). Münster: Waxmann.

Valdiviezo, L., \& Nieto, S. (2015). Culture in bilingual and multilingual education. In W. E. Wright, S. Boun, \& O. García (Eds.), Handbook of bilingual and multilingual education (pp. 92-108). Malden, MA: Wiley-Blackwell. https://doi.org/10.1002/9781118533406.ch6

Walde, M. (2004). Demographisch-statistische Betrachtungen im Oberlausitzer Gemeindeverband "Am Klosterwasser". Lětopis, 51(1), 3-27.

Wenger, E. (1998). Communities of practice: Learning, meaning, and identity. Cambridge: Cambridge University Press. https://doi.org/10.1017/CB09780511803932

Woolard, K. A. (2011). Is there linguistic life after high school? Longitudinal changes in the bilingual repertoire in metropolitan Barcelona. Language in Society, 40(5), 617-648. https://doi.org/10. $1017 / \mathrm{S} 0047404511000704$

Wot wustawy so jara zdaluja: Žadanje AfD, Serbow ličić, sylne reakcije zbudźiło. (2018, July 5). Serbske Nowiny.

Wright, W. E., Boun, S., \& Garcia, O. (2015). Handbook of bilingual and multilingual education. Malden: Wiley-Blackwell. https://doi.org/10.1002/9781118533406

\section{Funding details}

This article presents research which has been funded by a grant from the National Science Center, Poland entitled, "Language contact and culture conflict. Acquiring linguistic competence and cultural identity creation - the case of pupils in the Sorbian Grammar School in Bautzen (Upper Lusatia)" (UMO-2016/21/B/HS2/00001). Grant is affiliated at the Institute of Slavic Studies, Polish Academy of Sciences.

The authors declare that they have no competing interests. 
Both of the authors participated equally in preparing conception and academic editing of this issue.

This is an Open Access article distributed under the terms of the Creative Commons Attribution 3.0 PL License (http://creativecommons.org/licenses/by/3.0/pl/), which permits redistribution, commercial and non-commercial, provided that the article is properly cited.

(C) The Authors 2019

Publisher: Institute of Slavic Studies, Polish Academy of Sciences 